UDC: 336.025.2; 336.132.1(497.11:477) doi: $10.5937 /$ ekonhor1503189N

\title{
THE FRAMEWORK FOR FINANCIAL STABILITY: SERBIAN AND UKRAINIAN APPROACHES
}

\author{
Maryna Nikonova* \\ National Bank of Ukraine, Financial Stability Department, Kiev, Ukraine
}

The development and implementation of any policy require the creation of preconditions for ensuring the independence of such a policy. In order to provide such preconditions, it is necessary to build up an institutional framework and regulate the key principles of development and implementation of an appropriate policy. the macroprudential policy is no exception, either. The macroprudential policy is a new policy area, which aims to identify, analyze and counter risks to the financial system as a whole, as opposed to traditional microprudential regulation and supervision, whose focus is exclusively on the risks of individual institutions. In many countries, the processes of appropriate legislation and building an institutional framework are ongoing. The article is focused on a comparative analysis of the Serbian and the Ukrainian approaches to macroprudential policymaking. The differences and the similarities between the Ukrainian and the Serbian macroprudential policymaking models are generalized.

Keywords: macroprudential framework, macroprudential policy, model of macroprudential policymaking

\section{INTRODUCTION}

The activity of creating foundations to ensure the stability of the financial system as a whole is carried out at the international and national levels. The establishment of completely new policy areas - the macroprudential policy - is part of this activity. The macroprudential policy aims to identify, analyze and counter risks to the financial system as a whole, as opposed to traditional microprudential regulation and supervision, whose focus is exclusively focused on

\footnotetext{
* Correspondence to: M. Nikonova, Macroprudential Policy Division, Financial Stability Department, National Bank of Ukraine, 9 Instytutska St., 01601 Kiev, Ukraine; e:mail: maryna.nikonova@gmail.com
}

the risks of individual institutions (Bank of Lithuania, 2015). Thus, the ultimately purpose of macroprudential policy is to promote the stability of the financial system as a whole.

The process of establishing and implementing the basic principles of the macroprudential policy is being conducted in many countries today. There are different types of a macroprudential model in the world. Some countries implement similar approaches to creating a macroprudential model. Despite this, an externally similar model can have quite substantial differences that ultimately determine the effectiveness of such a model. The problem of the formation and functioning of macroprudentia,l models has been the subject matter of research, for example, done by G. Galati and 
R. Moessner (2010), G. Jiménez, S. Ongena, J-L. Peydro and J. Saurina (2012), G. Benigno (2013), and H. Daniel (2014).

At the same time, it is difficult to single out the research which would be devoted to a comparative analysis and the determination of the basis of certain macroprudential model challenges and possible ways of its improvement. It should be noted, according to the European Systemic Risk Board (ESRB) recommendation, that it is quite important that the leading role of the central bank should be ensured in every type of the macroprudential model.

At present, it is impossible for is to evaluate the effectiveness of a particular model. We are deeply convinced that this will determine the single criterion of truth - practice. At the same time, in our opinion, it is possible today to conduct a comparative analysis of macroprudential models identical in substance.

In our opinion ${ }^{1}$, it is possible to conduct a comparative analysis of essentially identical models in order to determine their features and advantages, and compile further directions of the possible development of such models, based on the results of the framework of an appropriate comparative analysis. The assessment of compliance with international organizations' recommendations on the macroprudential policy of similar models is also considered as important.

These are the reasons why it is essential that the issue of the internal structure of the macroprudential policy, based on a comparative analysis, should be given the leading role in this paper.

In accordance with the defined subject, the main aim of this paper is a critical analysis of different approaches in order to organize the macroprudential model, which is seen externally identical to similar. In other words, the aim is to prove that, at first sight, similar macroprudential models can have significant differences, which ultimately has an impact on the efficiency of such models and the implementation of the macroprudential policy.

In accordance with the subject and the purpose of the research, the initial hypothesis is:
$\mathrm{H}$ : If the same macroprudential model is introduced in countries by the external structure should identical assumptions regarding the effectiveness of such models be assumed.

Thus, this paper is directly devoted to the research into the institutional and legal frameworks (as the decisive aspects) of the macroprudential policy model identical in its construction in order to identify the possible ways of its improvement.

The paper is organized into five sections. Following the Introduction, the second section of the paper briefly justifies the choice of the countries for the comparative analysis of macroprudential models in these countries. The third section examines the institutional aspect of ensuring financial stability. This section examines the characteristics of each type of the macroprudential model, summarizes the advantages and the challenges. In this context, the organizational structures of central banks are also studied from the point of view of the fact that they have prerequisites for the proper implementation of the macroprudential policy. The fourth section examines the legislative aspect, in particular those rules relating to financial stability and the macroprudential policy. Based on this analysis, the benefits and omissions of the legislation of each of the surveyed countries (The Republic of Serbia and Ukraine) are determined. In the last section of the paper, i.e. the Conclusion, the author presents her own opinion on the set hypothesis, presents the key results of the research and notes the contribution and limitations of the study, simultaneously identifying the possible directions for further research.

Why have we chosen the Republic of Serbia and Ukraine? In order to achieve the defined objectives, we have chosen two countries with similar approaches to the implementation of the macroprudential policy and the maintenance of financial stability - namely the Republic of Serbia and Ukraine.

The main criteria that have led to our opting for conducting a comparative analysis of the macroprudential policies of Ukraine and the Republic of Serbia are as follows:

- the National Bank of Serbia and the National Bank of Ukraine carry out microprudential regulation 
and supervision, which shows that they have similar organizational structures;

- both countries have chosen the identical model of macroprudential policymaking - namely a committee outside the Central Bank, with the Central Bank participating on the macroprudential committee;

- neither of these two countries is a member-state of the European Union.

\section{THE INSTITUTIONAL FINANCIAL STABILITY FRAMEWORK}

Given the lessons learned from the crisis, the problem of the macroprudential policy has in recent years been treated as a specially urgent one by researchers and practitioners focused on various aspects of such a policy (International Monetary Fund, 2014).

The basic principle of the building of the model of macroprudential policymaking is generalized by the European Systemic Risk Board (ESRB 2011; ESRB, 2013).

Several researches have been devoted to determining the type of the macroprudential policymaking model and the features of different types of the macroprudential policymaking model (IMF, 2013; IMF, 2014; World Bank, 2014).

It should be noted that, in 2011, the level of the compliance with the recommendations for the macroprudential policy, mandated by national regulation and supervision (ESRB, 2014), was evaluated.

Today, the Financial Stability Board (FSB), the Basel Committee of Banking Supervision (BCBS), the European Systemic Risk Board (ESRB), the International Monetary Fund (IMF) and the World Bank continue their work on developing the framework's basic principles for the development and implementation of the macroprudential policy.

At the national level, it is an actuality that an appropriate institutional framework is created and the basic principles of the macroprudential policy development and implementation in legislation are defined.

The creation of legal and institutional frameworks required the implementation of the following measures (ESRB, 2014; ECB, 2015):

- determining the model of macroprudential policymaking and defining the authority responsible for the macroprudential policy;

- providing a broad and explicit macroprudential mandate, depending on the model, which enables the determining of the macroprudential goal, the macroprudential function and macroprudential powers by a national law.

As a result, in many countries, the processes of the appropriate legislation and building of an institutional framework are ongoing.

There are three basic models of macroprudential policymaking (IMF 2013a; IMF 2014; World Bank, 2014):

- the Board of the Central Bank (for example, the Czech Republic, New Zealand, Ireland).

- the Committee within the Central Bank (for example, the United Kingdom, Malaysia).

- the Committee outside the Central Bank (for example, Australia, the USA, the Republic of Serbia, Ukraine).

The first model is natural in integrated arrangements, where the central bank already concentrates the relevant regulatory and supervisory powers. Where supervisory and regulatory agencies are established outside the central bank, the assignment of the mandate to the central bank is usefully complemented by coordination mechanisms, such as a coordination committee, chaired by the central bank, and explicit powers assigned to the central bank to make recommendations to other regulatory bodies (as in Norway and Switzerland) (IMF 2013a; IMF 2014; World Bank, 2014).

The second set-up model can help counter the risk of dual mandates for the central bank, by creating dedicated objectives and decision-making structures 
for the monetary and the macroprudential policies even though both policy functions are under the roof of the central bank (IMF, 2013b). It also allows for separate supervisory agencies and external experts to participate on the decision-making committee. This can foster an open discussion of trade-offs that brings to bear a range of perspectives and helps discipline the powers assigned to the central bank (IMF 2013a; IMF 2014; World Bank, 2014).

The third model can accommodate a stronger role of the Ministry of Finance. The participation of the Ministry of Finance on the committee can be useful when changes in legislation are needed to expand the macroprudential toolkit or the regulatory perimeter and when the cooperation of the fiscal authority is needed to mitigate the systemic risk. Some of these benefits can alternatively be achieved by informal coordination arrangements, and the ability of the macroprudential authority to make soft recommendations to the Ministry of Finance (IMF 2013a; IMF 2014; World Bank, 2014).

As already noted, the model of macroprudential policymaking in the Republic of Serbia and Ukraine enables the establishing of a macroprudential model a committee outside the Central Bank. Thus, even in this situation, in accordance with the ESRB's, the IMF's, the World Bank's recommendations, the model should ensure the leading role of the Central Bank.

According to the information obtained from the National Bank of Serbia, the members of the Financial Stability Committee are the Governor of the National Bank of Serbia, the Minister of Finance, the Head of the DIA, the President of the Securities Commission, the Director of the Administration for the Supervision of Financial Institutions, the State Secretary at the Ministry of Finance, the NBS Vice-Governor in charge of financial stability, and the General Manager of the Banking Supervision Department (National Bank of Serbia, 2013).

In Ukraine, the members of the Financial Stability Board are: the Governor of the National Bank of Ukraine, the Minister of Finance of Ukraine, the Chairman of the National Commission on Securities and the Stock Market, the Chairman of the National
Commission for the State Regulation of the Financial Services Markets, the Director of the Deposit Guarantee Fund, the Deputy Chairman of the National Bank of Ukraine, the Deputy Minister of Finance of Ukraine (A Decree of the President of Ukraine, 2015).

The Financial Stability Committee in the Republic of Serbia will meet at least once quarterly and will be chaired by the Governor of the National Bank of Serbia (National Bank of Serbia, 2013, NBS Financial Stability).

In contrast to Ukraine, the activity of the Financial Stability Board provides the co-chairmanship of the Minister of Finance and the Governor of the National Bank of Ukraine. Decisions of the Board are recommendatory in nature (A Decree of the President of Ukraine, 2015).

Therefore, there is no ensuring of the leading role of the National Bank in Ukraine. Thus, despite the fact that both the Republic of Serbia and Ukraine are based on the same type of the macroprudential policymaking model, there are significant differences in their internal constructions.

The world's experience shows that if the Committee (a Council or a Board) are established outside the Central Bank, the leading role of the Central Bank can be achieved in different ways.

For example, in Australia, the Council of Financial Regulators (CFR) is the coordinating body for Australia's main financial regulatory agencies. It is a non-statutory body, whose role is to contribute to the efficiency and effectiveness of financial regulation and promote the stability of the Australian financial system (Australian CFR, 2015).

Its membership comprises the Reserve Bank of Australia (RBA), which chairs the Council; the Australian Prudential Regulation Authority (APRA); the Australian Securities and Investments Commission (ASIC); and the Australian Treasury. The CFR meet in person quarterly or more often, if circumstances require it. Meetings are chaired by the RBA Governor, with secretariat support provided by the RBA (Australian CFR, 2015). 
In the CFR, members share information, discuss regulatory issues and, if a need arises, coordinate responses to potential threats to financial stability. The CFR also advises the Government on the adequacy of Australia's financial regulatory arrangements (Australian CFR, 2015).

The Reserve Bank's mandate to uphold financial stability does not equate to a guarantee of solvency for financial institutions. The Bank does, however, have an important role in the management of crisis situations in co-operation with other CFR agencies. In particular, the Bank has a responsibility for monitoring financial markets, and payment and settlement systems, and for advising the Treasurer or another relevant Minister on an emerging distress in these markets and systems. In addition, the Bank has a responsibility for assessing and advising on the nature and the scale of the systemic impact of any significant financial stress, including implications for financial markets and payments system. The Bank is also responsible for evaluating and implementing response options that involve liquidity support or the use of payments system powers (Reserve Bank of Australia, 2015).

In Germany, the Bundesbank performs important functions within the Financial Stability Committee and brings its expertise in macroprudential and macroeconomic analyses as well as in the microprudential supervision of financial institutions and infrastructures to bear. The Bank analyzes the factors that are key to financial stability and identifies risks which may impair financial stability. In addition, it prepares the Financial Stability Committee's annual report to the Bundestag on the situation regarding and developments in financial stability in Germany. Lastly, it makes proposals to the Committee for the issuing of warnings and recommendations and evaluates their implementation by addressees (Bundesbank, 2013). The Bundesbank maintains its independence in all of the tasks designated to it as a member of the Financial Stability Committee (Germany Act, 2012).

It cannot be made to unwillingly participate in the adoption of the opinions or measures that it does not advocate, as the Financial Stability Committee cannot take key decisions contrary to the votes of the
Bundesbank representatives in attendance (Germany Act, 2012).

In France, the High Council for Financial Stability conducts the macroprudential policy as a collegiate body; the HCSF's oversight mandate is supplemented by the regulatory powers that enable it to activate the tools necessary for correcting the imbalances of the financial sector. The Governor of the Banque de France is empowered to make proposals for the activation of these macroprudential instruments (Le Lorier, 2014).

So, the leading role of the Central Bank on the Committee, which is established outside the Central Bank, is provided by the authority to preside over the Bank (the Republic of Serbia, Australia) (National Bank of Serbia, 2013, NBS Financial Stability; Reserve Bank of Australia, 2015); the veto representative of the Central Bank (Germany) (Germany Act, 2012); the Central Bank's exclusive right to make proposals for macroprudential instruments (France) (Le Lorier, 2014).

In addition, it is important that independence should be provided for the macroprudential authority. Thus, the macroprudential authority is minimally operationally independent, in particular from political bodies and the financial industry; and organizational and financial arrangements do not jeopardize the conduct of the macroprudential policy (ESRB, 2014).

In this context, the organizational structures of the National Bank of Serbia and the National Bank of Ukraine deserve to be paid special attention to. Thus, at the National Bank of Serbia, the Monetary Departments, the Microprudential Supervision Departments and the Financial Stability Department are different and separate units (blocks) (Figure 1).

In contrast to it, at the National Bank of Ukraine, the Monetary Policy Department and the Financial Stability Department are presented as one unit (block), whereas the Microprudential Supervision Departments constitute another separate unit (block) (Figure 2).

Thus, it is apparent that the Serbian Central Bank's organizational structure separates the process of the implementing of the monetary policy from the macroprudential policy, which approach is more 


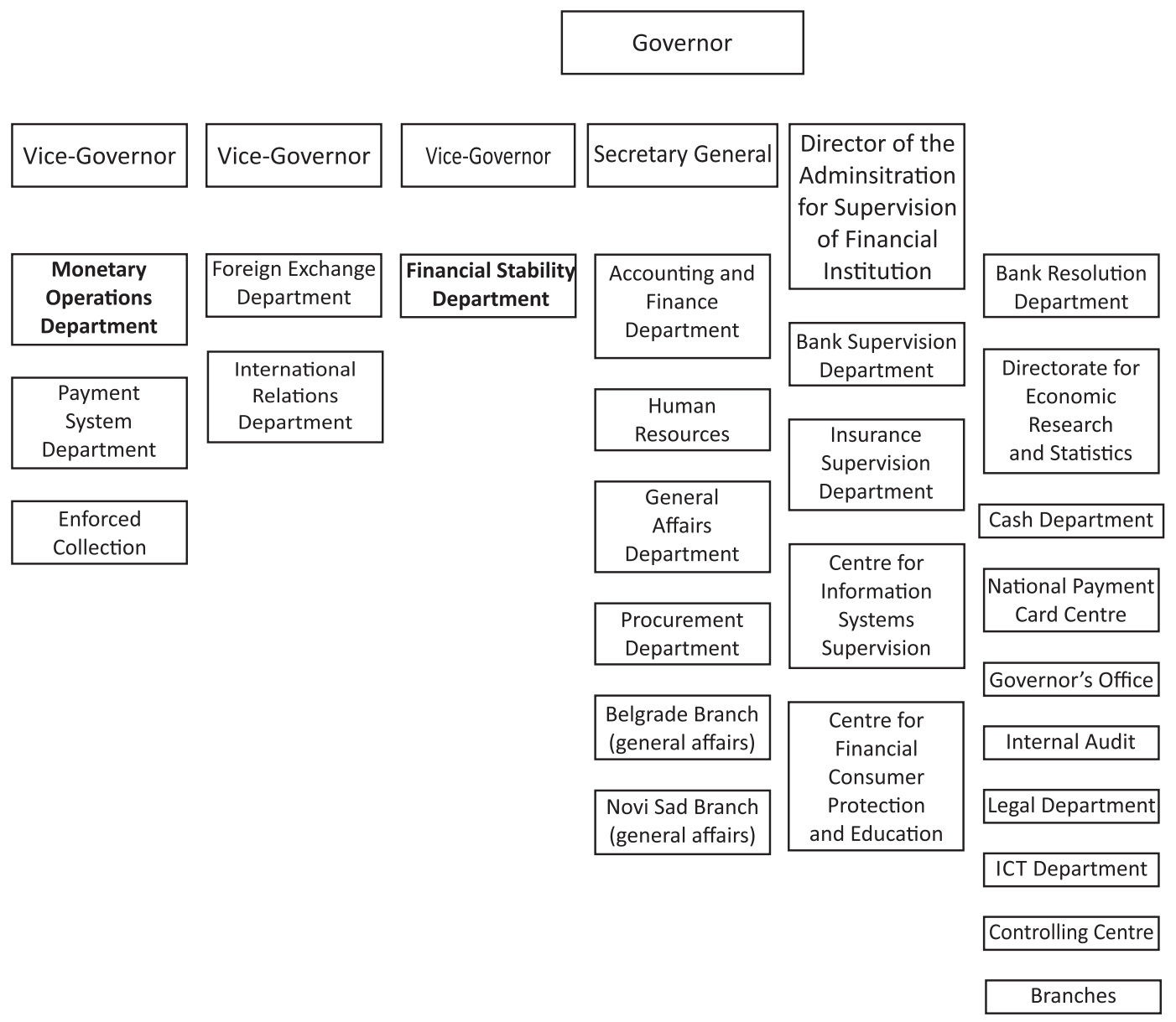

Figure 1 The organizational chart of the main units (blocks) of the National Bank of Serbia

Source: Organizational Structure of the NBS, http://www.nbs.rs/internet/english/10/10_5.html

acceptable in the world and causes a higher level of efficiency policies.

The importance of the separation (isolation, autonomy) of the Financial Stability Department is confirmed by the Central Bank organizational structures, even in those countries that operate the macroprudential institutional framework on the first model (the Board of the Central Bank - the Czech Republic) and the second model (the Committee within the Central Bank - the UK).

For instance, the organizational structure of the Czech National Bank provide us with evidence that, even in the case when the Board of the Central Bank is the macroprudential policymaking authority, the Monetary Department and the Financial Stability Department are separate structural units (Figure 3)

There is no exception in the case of the United Kingdom's model, where the Committee is established within the Bank of England. Thus, the Monetary Policy unit (block) and the Financial Stability unit (block) are the separate units of the Bank of England (Figure 4).

The above analysis of the Central Banks' organizational structures (which are the components of various kinds of macroprudential policymaking models) confirms the disunity of the Monetary Policy Unit and the Financial Stability Unit. This is primarily due to the 


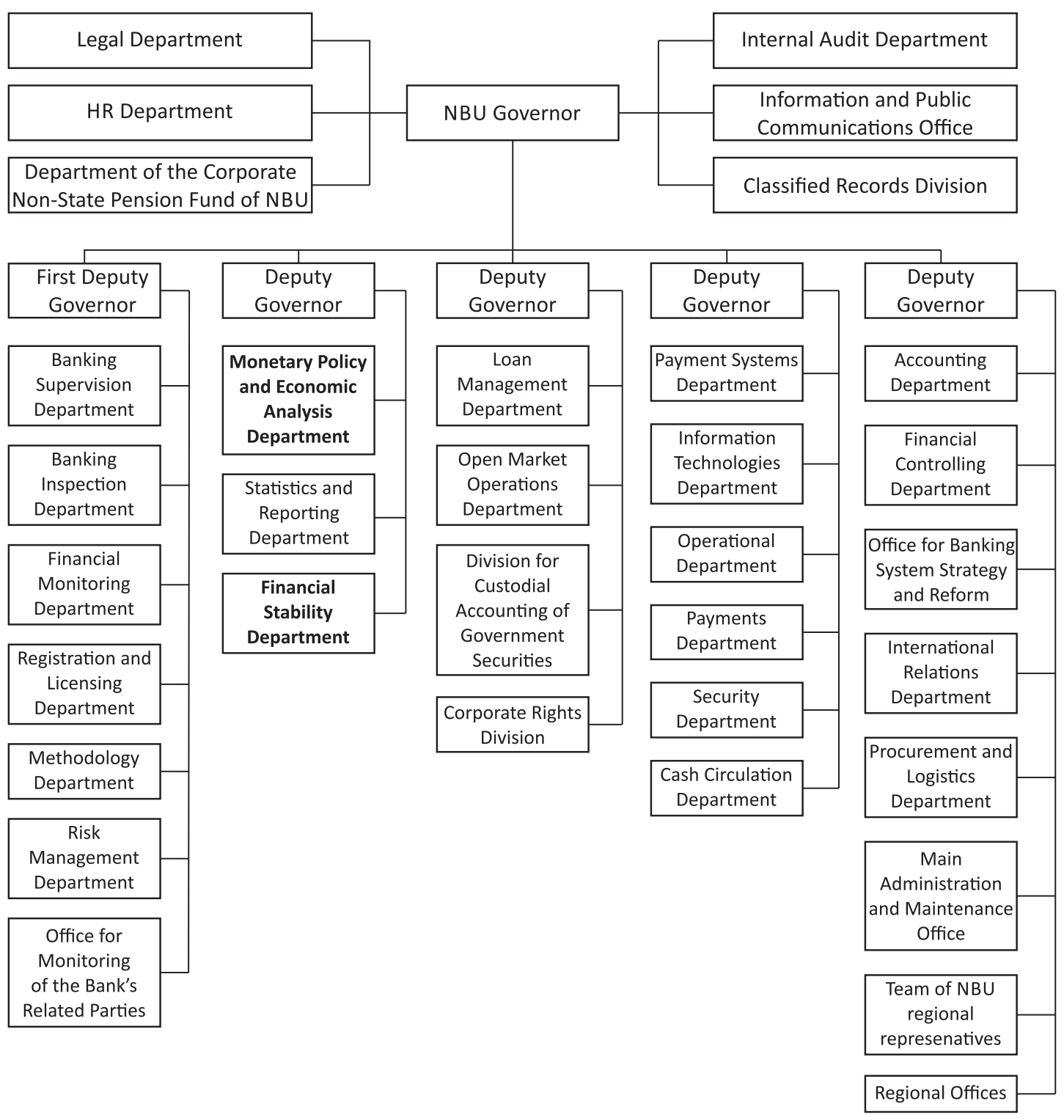

Figure 2 The organizational chart of the main units (blocks) of the National Bank of Ukraine

Source: Organizational Chart of the National Bank of Ukraine, http://www.bank.gov.ua/doccatalog/document?id=58674

difference between the goals of the macroprudential policy and the macroprudential policy itself.

The newly-emerging paradigm is the one in which both the monetary policy and macroprudential policies are used for countercyclical management: the monetary policy that is primarily aimed at the price stability; and the macroprudential policies that are primarily aimed at financial stability. But, these policies interact with each other, which allows each one of them to enhance or diminish the effectiveness of the other (Claessens \& Valencia, 2013).

The monetary policy and the macroprudential policy should generally reinforce one another (Angelini, Neri 


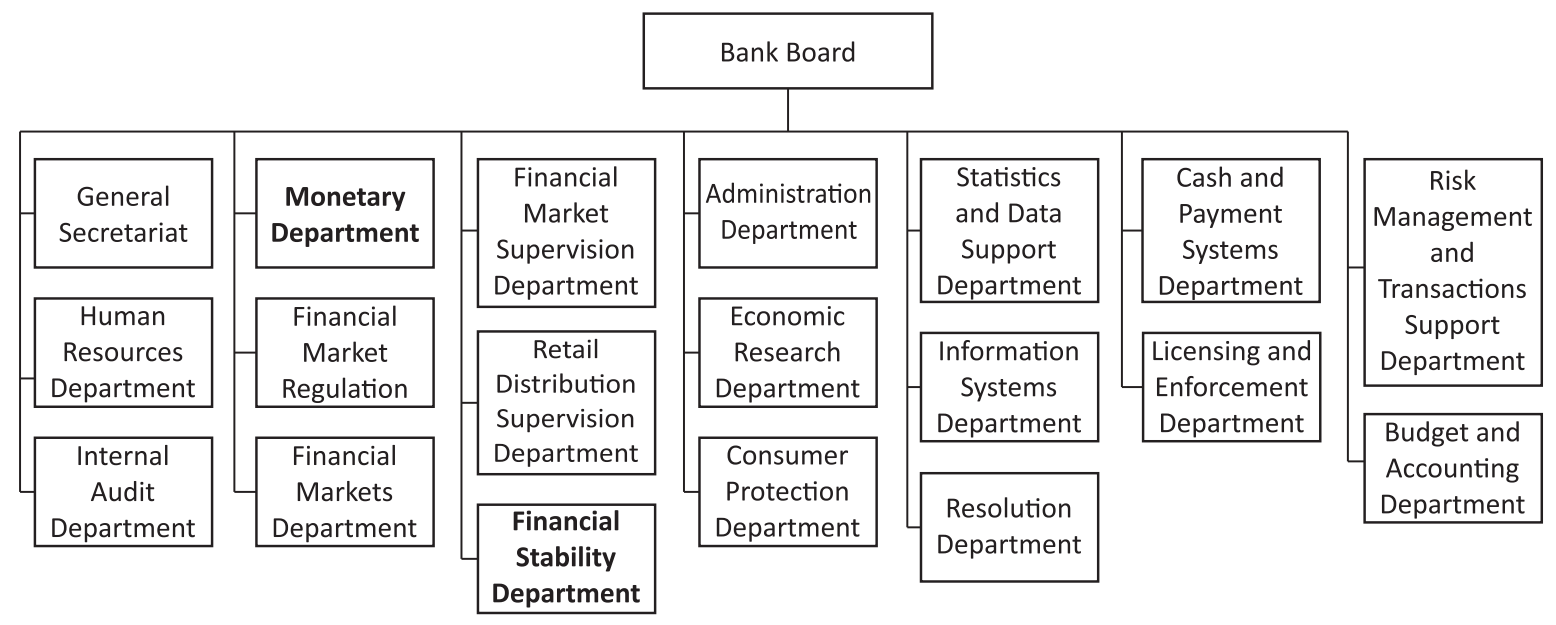

Figure 3 The organizational chart of the main units (blocks) of the Czech National Bank

Source: Organisational structure of the Czech National Bank, https://www.cnb.cz/miranda2/export/sites/www.cnb.cz/en/about_ cnb/org_structure/download/org_schema.pdf

\& Panetta, 2011), especially when one of the two is being faced with constraints (IMF, 2013b). Yet, the former policy does not guarantee the latter (and vice versa), and conflicts of objectives may arise, for example, in periods when the monetary policy does not prevent the asset price bubbles from arising. Nonetheless, using the estimated dynamic stochastic general equilibrium (DSGE) model with financial frictions, D. Beau, L. Clerc and B. Mojon (2012) show that „episodes of conflicts should be rather limited, on average, over the business cycle". Potential conflicts may be avoided by prioritizing objectives, implementing clear governance procedures (such as a strict separation of decision-making bodies between the monetary policy and the macroprudential policy) and using specific instruments for each objective (Bennani, Després, Dujardin, Duprey \& Kelber, 2014).

Thus, based on the analysis of the macroprudential policymaking model and the organizational structures

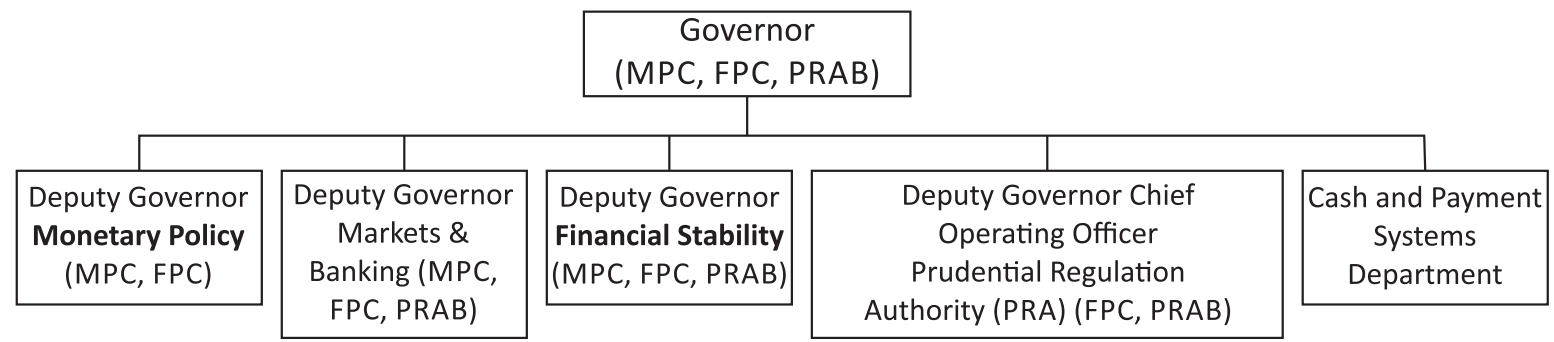

Notes: MPC - Monetary Policy Committee; FPC - Financial Policy Committee; PRAB - Prudential Regulation Authority Board

Figure 4 The organizational chart of the main units (blocks) of the Bank of England 
of the Central Banks, which are the components of such models, we can draw the following, but very important conclusion - regardless of the macroprudential policymaking model (the Czech Republic, the United Kingdom and the Republic of Serbia), the Central Banks' institutional frameworks clearly distinguish the monetary from the macroprudential policy functions, accompanied by separate decision-making, accountability and communication structures. In turn, the clarity distinction process of the development and implementation of monetary and macroprudential policies is an important precondition for the effectiveness of monetary and macroprudential policies.

Also, we fully agree with the IMF's position that the dominant role of the Ministry of Finance risks delaying the macroprudential action and can compromise the independence of participating agencies, including the central bank and separate supervisory agencies (IMF, 2013a; IMF 2014). Some of these risks can be countered by providing the leading role of the central bank.

\section{THE REVIEW OF THE LEGAL \\ FINANCIAL STABILITY FRAMEWORK}

It is noteworthy that in the Republic of Serbia in the post-crisis period a Memorandum on the Strategy of the Dinarization of the Serbian Financial System was adopted, with the aim of creating conditions for financial stability. The Memorandum on the Strategy of the Dinarization of the Serbian Financial System defines the objectives, measures and activities to be taken with a view to strengthening confidence in the national currency and promoting its use in the financial system (Government of the Republic of Serbia, 2012).

In the Republic of Serbia later on, in the late 2013, in order to promote formal cooperation amongst the institutions included in the supervisory and the regulatory financial system frameworks, the Government of the Republic of Serbia, the National Bank of Serbia, the Deposit Insurance Agency and the Securities Commission established a separate inter- institutional body - the Financial Stability Committee (the Committee).

In Ukraine, by the Presidential Decree on the Establishment of the Financial Stability Board in March 2015 (A Decree by the President of Ukraine, 2015), established a separate inter-institutional body - the Financial Stability Board (the Board). Both the Financial Stability Committee in the Republic of Serbia and the Financial Stability Board in Ukraine are defined by the national Law as advisory bodies.

In the Republic of Serbia, the Committee operates as an advisory body, with the task of discussing and assessing issues of the financial system stability and the possible measures that can be implemented in order to maintain it. The Committee acts towards strengthening mutual cooperation and harmonizing policies and measures implemented by institutions, in accordance with their responsibilities, for the purpose of safeguarding and strengthening the financial system stability. The Committee has established a system for maintaining a regular dialogue between the relevant authorities and a system of communication lines in crises (National Bank of Serbia, 2015).

According to the Agreement of Cooperation for the Purpose of the Preservation of the Financial Stability in the Republic of Serbia, in order to ensure the implementation of this Agreement, the National Bank of Serbia shall coordinate activities envisaged thereunder. To ensure efficient coordination and the achievement of its objective, the Parties shall set up a Financial Stability Committee, comprising the Governor, as its Chair, the Minister of Finance, the Director of the Deposit Insurance Agency and other members appointed by the RoS's Government and the National Bank of Serbia (Government of the Republic of Serbia, Agreement of cooperation for the preservation of financial stability in the Republic of Serbia).

Furthermore, in the Agreement of Cooperation for the Purpose of the Preservation of the Financial Stability in the Republic of Serbia, it is clearly defined that, „in order to preserve financial stability, the National Bank of Serbia shall undertake measures falling within the scope of its authority (Government of the Republic of 
Serbia, Agreement of cooperation for the preservation of financial stability in the Republic of Serbia):

- the granting and revoking operating licenses of banks and the supervision of banks' operations;

- the granting and revoking of licenses for performing insurance operations and the supervision of insurance operations;

- the granting and revoking of licenses of other entities within the Financial Sector, which are supervised by the National Bank of Serbia;

- the organizing, overseeing and development of both domestic and foreign payment operations;

- the independent conduct of the exchangerate policy and the selection of the exchangerate regime, upon consent obtained from the Government of the Republic of Serbia".

The National Bank of Serbia's mandate for the implementation of the macroprudential policy stems from Article 4, Item 3 of the Law on the National Bank of Serbia (the NBS Law) („,The Official Gazette of RoS”, Nos 72/2003, 55/2004, 85/2005 - and other laws, 44/2010, 76/2012, 106/2012 and 14/2015), which stipulates that the National Bank of Serbia "shall determine and implement, within its scope of authority, the activities and measures aimed at maintaining and strengthening the stability of the financial system" (National Bank of Serbia, 2015).

As part of the financial stability measures and activities, the National Bank of Serbia conducts regular and comprehensive analyses of the macroeconomic environment and the functioning of the key financial institutions, markets and infrastructure; identifies risks that pose a threat to the stability of the financial system; identifies the trends that may increase the vulnerability of the financial system; and launches debates on new regulatory initiatives and their potential effect on the financial system and the real sector of the economy. The National Bank of Serbia acts both preventively and correctively by changing the financial regulatory framework. If necessary, the National Bank of Serbia also manages the consequences of external shocks and other crisis situations, lessening potentially negative effects on financial stability (National Bank of Serbia, Financial Stability).

In Ukraine, Article $7^{1}$ of the Law on the National Bank of Ukraine (the NBU Law), defined the features of maintaining the stability not of the financial system, but rather the banking system.

It should be noted that the so-called macroprudential goal is defined in the national laws in both Serbia and Ukraine. However, in our opinion, there are some differences in the interpretation of these goals.

For example, Article 3 of the Law on the National Bank of Serbia defines that: „,without prejudice to its primary objective, the National Bank of Serbia shall contribute to the maintaining and strengthening of the stability of the financial system".

In Ukraine, according to Article 6 of the Law on the National Bank of Ukraine, „the National Bank, within its powers, contributes to financial stability, including the stability of the banking system, provided that, if it does not prevent the achievement of the objectives specified in part two of this article (the Author's note the objectives specified in part two of this article shall mean achieve and maintain the price stability).

Therefore, the Serbian Law and the Ukrainian Law formulate the macroprudential goal in quite a similar manner. In our opinion, however, the Serbian approach is more effective with respect to creating conditions for the effective development and implementation of the monetary and the macroprudential policies (mentioned above).

\section{CONCLUSION}

According to the comparative analysis, the following conclusions can be drawn.

Firstly, it is impossible to make an assessment of the institutional macroprudential framework only by the types of the macroprudential policymaking model. The survey revealed that the level of the efficiency of the institutional macroprudential framework (in our case in the Republic of Serbia and Ukraine) also depends on several criteria: distinguishing the functions of 
the monetary and the macroprudential policies, the separation of decision-making between the monetary and the macroprudential policies, the accountability and the communication structures of its policies.

Secondly, during the study of the Central Banks' institutional structure of some countries that represent a variety of approaches to organize the macroprudential policymaking model, we found out that, in all the countries surveyed (the Czech Republic, the UK and the Republic of Serbia), the monetary unit and the financial stability unit are separated from each other. Contrary to that, there is no such separation in Ukraine.

Thirdly, we consider the Serbian approaches as more advanced. On the one hand, the Serbian approaches are fully consistent with the European Systemic Risk Board (ESRB, 2011; ESRB, 2014). Especially in the context of the following: "regardless of the model for the macroprudential policy according to the ESRB's recommendation, 'national central banks should have a leading role in macro-prudential oversight because of their expertise and their existing responsibilities in the area of financial stability'". This conclusion is further strengthened when central banks are also in charge of microprudential supervision. In addition, a detailed analysis of the legal and the institutional frameworks gives grounds to an argument that the Serbian approach more accurately defines the authority's responsibility for maintaining the stability of the financial system and the implementation of the macroprudential policy.

On the other hand, in our opinion, the organizational structure the National Bank of Serbia provides a possibility of creating favorable conditions for the independent implementation of the macroprudential policy, which is primarily provided by the monetary and the financial stability units.

Fourthly, the external manifestation of the macroprudential policymaking model does not mean its internal similarity. We must note some different features in, at first glance, seemingly identical models of macroprudential policymaking in the Republic of Serbia and in Ukraine. The similar features are the following:
- the advisory nature of Financial Stability Committee (in the Republic of Serbia) and Financial Stability Board (in Ukraine);

- the Committee in the Republic of Serbia and the Board in Ukraine include representatives of different authorities, whose activities are connected with the maintaining of the stability of the financial system;

- both the Financial Stability Committee (in the Republic of Serbia) and the Financial Stability Board (in Ukraine) are designed to implement the decision-making process;

The main different features of the macroprudential policymaking models in the Republic of Serbia and in Ukraine are the following:

- the leading role to promote financial stability in the Republic of Serbia belongs to the National Bank of Serbia;

- the chairperson of the Financial Stability Board is the Governor of the National Bank of Serbia. The Minister of Finance and the Governor of the National Bank of Ukraine are the cochairpersonship of the Financial Stability Board in Ukraine.

- the National Bank of Serbia is endowed by mandate for the implementation of the macroprudential policy, which it is allowed to do under the national Law (The Law on the National Bank of Serbia). The national Law on the National Bank of Ukraine determines the macroprudential goal of the National Bank of Ukraine;

- determining the macroprudential goal at the national laws of the Republic of Serbia and Ukraine is not conducted similarly. In the Republic of Serbia, there is no clear convention of the implementation activities for maintaining the stability of the financial system, which is primarily provided by the separation of the monetary and the macroprudential policies.

Fifthly, given the foregoing, we consider the separation of the monetary and the financial stability units of the National Bank of Ukraine. And we fully agree with the 
IMF's position that the dominant role of the Ministry of Finance risks delaying the macroprudential action and can compromise the independence of participating agencies, including the Central Bank and separate supervisory agencies. In Ukraine, it can be neutralized by ensuring the macroprudential leading role of the National Bank of Ukraine. It can be done, as the same has been evidenced by the world's experience, in different ways (enabling the presiding of the Central Bank; the veto of the Central Bank's representative; an exclusive right to make proposals for macroprudential instruments of the Central Bank). At the same time, it is also required that the macroprudential goal should be clarified, that the macroprudential function and macroprudential powers should be provided by the national law, thus giving the National Bank of Ukraine a clear macroprudential policy mandate.

Thus, the contribution of this paper can be seen in the critical analysis of different approaches to organizing the externally identical macroprudential model, on the one hand, and the comparative analysis aimed at identifying possible approaches to improving the institutional and legal aspects (in our case - the Ukrainian macroprudential model), on the other. Beside this, the contribution of this paper can also be seen in the importance of the legal and institutional aspects of the creation of the preconditions for the effective implementation of the macroprudential policy.

Simultaneously, the organizational structure of the macroprudential model is seen as an important prerequisite, rather than a panacea of ensuring the effective implementation of the macroprudential policy. After all, the effectiveness of the model lies in its being primarily an effective and efficient mechanism for the approval of decisions, whereas the indicators and tools of the macroprudential policy are also an equally important part of ensuring the success of such a policy.

Certainly, the paper is focused on the one of the key aspects of the development and implementation of the macroprudential policy. At the same time, the key limitations to this research are found in the fact that the formation of the macroprudential policy areas is still in progress. Given this fact, further research into the macroprudential policy and financial stability can be focused on the developing of the methodology of the application of macroprudential instruments in Ukraine and determining the transmission mechanisms of systemic risks.

\section{ENDNOTE}

1 The views expressed herein are those of the authoress and may therefore in no way be taken to reflect the official opinion of the National Bank of Ukraine.

\section{REFERENCES}

Angelini, P., Neri, S., \& Panetta, F. (2011). Monetary and macroprudential policies. Banca d'Italia, Working Papers, No. 801.

Australian CFR. (2015). Council of Financial Regulators. http:// www.rba.gov.au/fin-stability/reg-framework/cfr.html

Bank of Lithuania. (2015). The Macro-prudential Policy Strategy - Resolution of the Board of Lithuania on the approval of the macroprudential policy strategy. No 03-31. http://www.lb.lt/ strategy

Beau, D., Clerc, L., \& Mojon, B. (2012). Macroprudential policy and the conduct of monetary policy. Banque de France, Working Paper, No. 390.

Bennani, T., Després, M., Dujardin, M., Duprey, T., \& Kelber, A. (2014). Macroprudential framework: key questions applied to the French case. Banque de France Financial Stability Directorate, Occasional papers, No. 9. https://www.banquefrance.fr/fileadmin/user_upload/banque_de_france/ publications/OP9_Macroprudential-framework.pdf

Benigno, G. (2013). Commentary on Macroprudential Policies. International Journal of Central Banking, 9(1), 287-297.

Bundesbank. (2013). Macroprudential oversight in Germany: framework, institutions and tools. Deutsche Bundesbank Monthly Report. 39-54. https://www.bundesbank.de/ Redaktion/EN/Downloads/Publications/Monthly_Report_ Articles/2013/2013_04_macroprudential_oversight.pdf?__ blob=publicationFile

Claessens, S. \& Valencia, F. (2013). The interaction between monetary and macroprudential policies. http://www. voxeu.org/article/interaction-between-monetary-andmacroprudential-policies 
A Decree of the President of Ukraine. (2015). Presidential Decree on Establishment of the Financial Stability Board. http://zakon3. rada.gov.ua/laws/show/170/2015.

European Central Bank. (2015). Towards a macroprudential framework for the single supervisory area. https://www. bankingsupervision.europa.eu/press/speeches/date/2015/ html/se150420.en.html

European Systemic Risk Board. (2011). Recommendation on the macro-prudential mandate of national authorities. http://www. esrb.europa.eu/pub/pdf/ESRB_Recommendation_on_ National_Macroprudential_Mandates.pdf?87d545ebc9fe76 $76 \mathrm{~b} 6 \mathrm{c} 545 \mathrm{~b} 6 \mathrm{bad} 218 \mathrm{c}$

European Systemic Risk Board. (2013). Recommendation on intermediate objectives and instruments of macroprudential policy. https://www.esrb.europa.eu/pub/pdf/ recommendations/2013/ESRB_2013_1.en.pdf?1b1664970cda9 e6fae046cdbf1bff91d

European Systemic Risk Board. (2014). Recommendation on the macro-prudential mandate of national authorities. Follow-up Report, Overall assessment. https://www.esrb.europa.eu/ pub/recommendations/html/index.en.html

Galati, G., \& Moessner. R. (2010). Macroprudential policy - a literature review. Working Paper No 267. De Nederlandsche Bank NV, Amsterdam. http://onlinelibrary.wiley.com/ journal/10.1111/(ISSN)1467-6419

German Act. (2012). Act to strengthen German financial supervision. Gesetz zur Stärkung der deutschen Finanzaufsicht. On October 25, 2012.

Government of the Republic of Serbia. (2012). Memorandum on the Strategy of Dinarisation of the Serbian financial system. http://www.nbs.rs/export/sites/default/internet/english/30/ memorandumvladadinarizacija_20120406_eng.pdf

Government of the Republic of Serbia. Agreement of cooperation for the preservation of financial stability in the republic of Serbia. http://www.nbs.rs/export/sites/default/internet/english/18/ sporazum_vlada_nbs_aod_fin_stabilnost.pdf.

Heath, D. (2014). International Coordination of Macroprudential and Monetary Policy. Georgtown Journal of International Law, 45, 1093-1136.

International Monetary Fund. (2013a). Key aspects of macroprudential policy. IMF Policy Paper. https://www.imf. org/external/np/pp/eng/2013/061013b.pdf

International Monetary Fund. (2013b). The Interaction of Monetary and Macroprudential Policies. IMF Policy Paper.
International Monetary Fund. (2014). Staff Guidance note on Macroprudential Policy. IMF Policy Paper., http://www.imf. org/external/np/pp/eng/2014/110614.pdf

Jiménez, G., Ongena, S., Peydró, J. L., \& Saurina, J. (2012). Macroprudential Policy, Countercyclical Bank Capital Buffers and Credit Supply: Evidence from the Spanish Dynamic Provisioning Experiments. Working Paper No. 231, National Bank of Belgium.

Lorier, A. Le. (2014). Macroprudential policy in France: requirements and implementation. Bank de France, No 18. https://www.banque-france.fr/fileadmin/user_upload/ banque_de_france/publications/FSR18_LeLorier.pdf

National bank of Serbia. (2013). Constitutive Meeting of Financial Stability Committee Held at NBS. http://www.nbs.rs/internet/ english/scripts/showcontent.html?id=6930\&konverzija=yes

National Bank of Serbia. (2015). Macroprudential framework: consultation document. http://www.nbs.rs/export/sites/default/ internet/english/18/macroprudential_framework_201503. pdf.

National bank of Serbia. Financial Stability. http://www.nbs.rs/ internet/english/18/index.html

National bank of Serbia. Law on the National Bank of Serbia. http://www.nbs.rs/export/sites/default/internet/english/20/ laws/law_nbs.pdf.

National Bank of Ukraine. Law on the National Bank of Ukraine. $\quad$ http://zakon3.rada.gov.ua/laws/show/679-14/ print1442833034369635.

Organisation chart of the Bank of England, http://www. bankofengland.co.uk/about/Documents/pdfs/orgchart.pdf

Organizational Chart of the National Bank of Ukraine, http:// www.bank.gov.ua/doccatalog/document?id=58674

Organisational structure of the Czech National Bank, https:// www.cnb.cz/miranda2/export/sites/www.cnb.cz/en/about_ cnb/org_structure/download/org_schema.pdf

Organizational Structure of the NBS, http://www.nbs.rs/ internet/english/10/10_5.html

Reserve Bank of Australia. Role of the Reserve Bank in Maintaining of financial Stability. http://www.rba.gov.au/fin-stability/rba. html.

World Bank. (2014). Macroprudential Policy Framework: A practice guide. Policy Paper, No 87810, World Bank. 
Received on $27^{\text {th }}$ October 2015 ,

after two revisions,

accepted for publication on $15^{\text {th }}$ December 2015.

Published online on $25^{\text {th }}$ December 2015.

Maryna Nikonova is a PhD, senior economist at the Macroprudential Policy Division of the Financial Stability Department of the National Bank of Ukraine. She graduated from the Kyiv National University of Economics. The key areas of her scientific research interests are the post-crisis development of the financial sector of Ukraine and approaches to the implementation of the macroprudential policy.

\title{
OKVIR ZA FINANSIJSKU STABILNOST: PRISTUPI REPUBLIKE SRBIJE I UKRAJINE
}

\author{
Maryna Nikonova \\ National Bank of Ukraine, Financial Stability Department, Kiev, Ukraine
}

Razvoj i sprovođenje bilo koje politike zahtevaju stvaranje preduslova, kojima bi se obezbedila nezavisnost takve politike. Da bi se stvorili preduslovi za to, neophodno je izgraditi institucionalni okvir i regulisati ključna načela razvoja i sprovođenja odgovarajuće politike. Ni makroprudencijalna politika ne predstavlja izuzetak. Makroprudencijalna politika spada u novu oblast politika, koje imaju za cilj da prepoznaju i analiziraju rizike za finansijski sistem $\mathrm{u}$ celini, i da se tim rizicima suprotstave, za razliku od tradicionalne mikroprudencijalne regulative i nadzora, koji su isključivo usredsređeni na rizike koji prete pojedinačnim ustanovama. U mnogim zemljama, u toku je proces donošenja zakona i izgradnje institucionalnog okvira. Ovaj rad je fokusiran na uporednu analizu pristupa donošenju makropudencijalne politike, koji se koriste $u$ Republici Srbiji i Ukrajini. Dat je opšti prikaz razlika i sličnosti između modela donošenja makroprudencijalne politike u Republici Srbiji i Ukrajini.

Ključne reči: makroprudencijalni okvir, makroprudencijalna politika, model donošenja makroprudencijalne politike

JEL Classification: G28 